\title{
PERANCANGAN ZINE SEBAGAI MEDIA KAMPANYE SOSIAL PEDULI PILPRES 2019 UNTUK PEMILIH PEMULA (GENERASI Z)
}

\author{
Lily Elserisa \\ Pascasarjana Institut Seni Indonesia Yogyakarta \\ E-mail: lilyelserisa@gmail.com
}

\begin{tabular}{|c|c|}
\hline ARTICLE INFO & ABSTRAK \\
\hline $\begin{array}{l}\text { Article history: } \\
\text { Received: } 4 \text { Mei } 2020 \\
\text { Revised: } 16 \text { Mei } 2020 \\
\text { Accepted: } 18 \text { Mei } 2020\end{array}$ & $\begin{array}{l}\text { The concern of novice voters in the Indonesian Presidential Elections } \\
2019 \text { was declining due to bad political problems. This made them } \\
\text { politically apathetic. Many social campaigns have tried to voice this, } \\
\text { but have not yet had an impact because they are buried by the swift }\end{array}$ \\
\hline $\begin{array}{l}\text { Keywords: } \\
\text { Novice Voters } \\
\text { Social Campaign } \\
\text { Zine }\end{array}$ & $\begin{array}{l}\text { flow of information in digital media. The campaigns also do not yet } \\
\text { have a message and media selection strategies that are close to the } \\
\text { novice voters which is part of generation z. The author carries out this } \\
\text { design using the Design Thinking method from Tim Brown (2009). In } \\
\text { this design, the author creates visual communication for a social } \\
\text { campaign. The verbal and visual message strategies adapted from } \\
\text { Lakoff and Johnson's metaphor theory (2003). In selecting media, the } \\
\text { author considering generation } z \text { and digital theory from Stillman } \\
\text { (2017). That theory supported by the concept of media synergy from } \\
\text { Djito Kasilo (2008). Those strategies are applied in e-zines and } \\
\text { printed zine so the message of the social campaign can be accepted by } \\
\text { novice voters in real and virtual spaces. }\end{array}$ \\
\hline
\end{tabular}

\section{PENDAhUluan}

Fenomena relawan yang muncul pada Pemilihan Umum Presiden dan Wakil Presiden (Pilpres) 2014 melahirkan semangat baru dalam praktik demokrasi Indonesia. Beberapa kelompok masyarakat mulai memberikan dirinya dengan bergerak di dunia maya untuk mengampanyekan partisipasi dalam Pilpres 2014. Gerakan tersebut berdampak bagi pengguna media sosial yang merupakan pemilih muda (17-30 tahun). Gerakan relawan tersebut pun membawa Joko Widodo dan Jusuf Kalla memimpin masyarakat Indonesia selama 5 tahun, namun banyak kebijakan dan kejadian politik yang menghadirkan pengalaman kurang baik bagi masyarakat, seperti: semakin banyaknya pejabat publik yang terlibat kasus korupsi, merebaknya isu SARA dalam wilayah politik, berbagai bencana yang dipolitisasi, ujaran kebencian dalam berpolitik di berbagai media, dan semakin hilangnya figur pejabat publik yang bisa diteladani. 
Kekecewaan publik terhadap pemerintahan dan fenomena politik tersebut bukan hanya menyurutkan semangat relawan, namun juga optimisme generasi muda yang sudah terbentuk sejak Pilpres 2014. Generasi muda yang dimaksud adalah pemilih muda yang sudah pernah mengikuti Pilpres maupun pemilih pemula yang akan mengikuti Pilpres di 2019. Penulis melakukan jajak pendapat melalui Instagram dan wawancara melalui Whatsapp pribadi kepada pemilih pemula pada tanggal 2 Oktober 2018 dan menemukan beberapa alasan pemilih pemula dalam kelompok generasi z memilih apatis dalam Pilpres 2019, antara lain: pemahaman politik yang kurang, malas mengurus administrasi Pemilu 2019, bingung dan takut salah memilih pemimpin, pesimis terhadap masa depan bangsa, dan kurangnya literasi yang kekinian seputar politik. Kondisi tersebut dihadapkan pada fakta bahwa pada Pilpres 2019 jumlah pemilih pemula, yakni warga yang berusia 17 tahun pada 1 Januari 2018 hingga April 2019 cukup besar, yakni 5.035.887 orang (Pemaparan Direktorat Jenderal Kependudukan dan Pencatatan Sipil Kementerian Dalam Negeri yang ditulis dalam halaman Kompas Online, 2018). Jumlah ini merupakan jumlah yang signifikan, sebab satu suara pemilih pemula dapat menentukan nasib bangsa.

Kampanye kesadaran mengenai pentingnya kepedulian pemilih pemula terhadap Pilpres 2019 sudah banyak disampaikan melalui media digital karena generasi Z memang akrab dengan dunia digital, seperti: KPU Goes to School dan \#Millenialsmemilih dari IDN Times, namun dampaknya belum terasa. Hal tersebut terbukti dengan hasil riset penulis yang telah penulis sebutkan di atas. Penulis berpendapat, ada hal-hal yang menyebabkan kampanye di media digital tidak berjalan dengan semestinya. Pertama, arus informasi yang diterima oleh generasi $\mathrm{Z}$ di internet sangat cepat, mulai dari informasi mengenai gaya hidup hingga berita yang belum tentu kebenarannya, bernada rasis, dan menyebarkan kebencian. Hal tersebut membuat kampanye sosial di media digital menjadi tersamarkan. Kedua, dimungkinkan kampanye-kampanye sosial yang ada tidak dirancang dengan strategi pesan dan media yang dekat dengan pemilih pemula. Hal ini membuat pemilih pemula merasa bahwa politik merupakan hal yang jauh dengan kehidupan mereka.

Berdasarkan permasalahan tersebut, perancangan ini bertujuan untuk membuat komunikasi visual dengan strategi yang dapat membuat pemilih pemula (generasi z) merasa dekat dengan pesan dalam kampanye sosial tersebut. Selain itu, melihat derasnya arus informasi di internet, penulis mencoba sebuah alternatif media dengan memadukan 2 jenis media komunikasi visual, yakni digital dan cetak (fisik). Perpaduan ini diambil dengan mempertimbangkan teori dari Stillman (2017), yang mengungkapkan sifat menarik dari generasi z, yakni Figital. Sifat ini merupakan penggabungan dari kata fisik dan digital. Generasi z cenderung memadukan antara sisi 
fisik dan digital dalam aspek hidupnya. Perpaduan media juga didukung oleh teori dari Kasilo (2008) mengenai sinergi antarmedia.

Penulis mempraktikkan perpaduan media dalam perancangan ini dengan media zine sebab zine merupakan media alternatif dari media arus utama. Pada perancangan ini, penulis mencoba paduan media sehingga pesan kampanye sosial dapat mengisi ruang fisik dan ruang digital dari generasi z. Penulis juga berharap perancangan ini mampu menghadirkan pesan kepedulian yang dekat dengan target audiens. Perancangan ini menambahkan alternatif komunikasi visual dalam kampanye sosial tentang pentingnya kepedulian terhadap politik untuk generasi muda yang sudah ada dan memperbaiki dengan tahap-tahap perancangan yang dilakukan penulis, yaitu: empati, referensi teori, dan hasil studi baik literasi dan lapangan. Penulis berharap, selain meningkatkan kesadaran pemilih pemula untuk peduli pada Pilpres 2019, perancangan ini juga dapat memberikan inspirasi bagi perancangan komunikasi visual dalam kampanye sosial kepada generasi z untuk menumbuhkan kepedulian terhadap praktik demokrasi di Indonesia di masa yang akan datang.

\section{METODE PERANCANGAN}

Perancangan ini mengadaptasi dan mengembangkan metode perancangan Design Thinking dari Tim Brown (2009). Design Thinking merupakan metode penyelesaian masalah yang berfokus pada pengguna yang terdiri dari 5 tahap, yakni: empathise, define, ideate, prototype dan test. Metode perancangan ini dipilih karena membuka kesempatan bagi desainer untuk melakukan eksperimen terhadap ide baru yang inovatif dengan tetap pada manusia dan kebutuhannya. Adapun bagan Design Thinking, sebagai berikut:

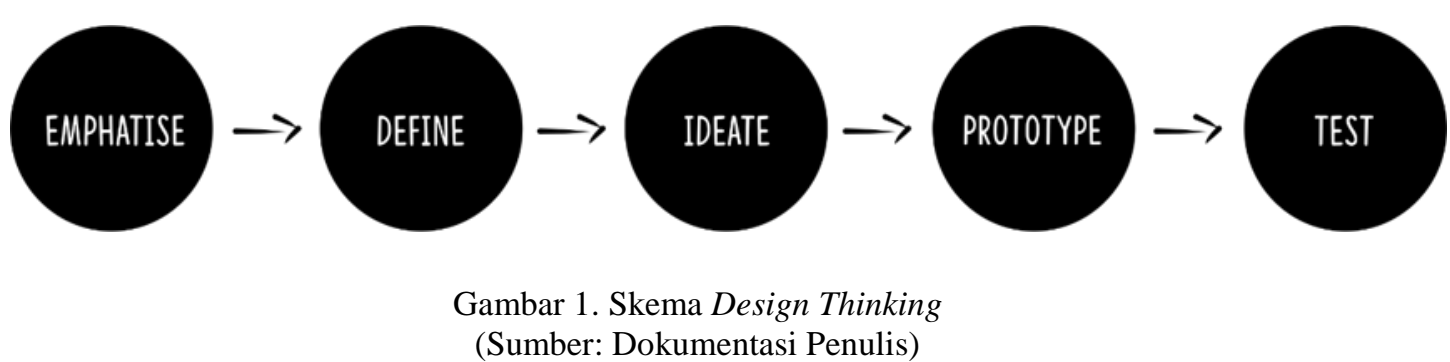

Emphatise merupakan tahap pertama, yang merupakan pemahaman empatik penulis mengenai permasalahan yang ada dan apa kebutuhan manusia di dalamnya. Pada perancangan ini, penulis melakukan pengamatan melalui penelusuran digital mengenai permasalahan dan kebutuhan yang dihadapi oleh para pemilih pemula melalui data-data yang disajikan oleh media yang terpercaya (Kompas dan Tirto.id). Selain itu, untuk mengonfirmasi data tersebut, penulis juga melakukan jajak pendapat melalui media sosial Instagram dan wawancara daring melalui 
aplikasi WhatsApp pada tanggal 2 Oktober 2018 untuk menemukan beberapa alasan pemilih pemula dalam kelompok generasi z memilih apatis dalam Pilpres 2019

Tahap kedua yakni, Define. Pada tahap ini penulis merumuskan masalah, menetapkan tujuan perancangan, dan menentukan target audiens. Lebih dalam lagi, penulis juga melakukan studi pustaka dari Stillman (2017) untuk mengenal karakter dan kebutuhan komunikasi visual target audiens. Pada tahap ini, penulis menentukan tujuan kampanye sosial dalam perancangan ini melalui teori dari (Bloom dan Novelli, 1981 dalam Sharma, et.al 2012).

Tahap ketiga, yakni, Ideate. Pada tahap ini, penulis menyusun konsep perancangan mulai dari memetakan target audiens berdasarkan demografi, geografi, psikografi, dan perilaku. Kemudian penulis melakukan pemilihan media, yakni media zine yang dikembangkan dari kajian Bartel (2004) dan didukung oleh ide mengenai sinergi antarmedia dari Kasilo (2008). Strategi pesan verbal dan visual pada perancangan ini berpijak pada teori metafora dari Lakoff dan Johnson (1980).

Tahap keempat adalah memvisualisasikan ide tersebut. Tahap ini disebut dengan Prototype. Pada tahap ini, penulis memasukkan pesan verbal dan pesan visual ke dalam media zine. Penulis memadukan zine cetak dan zine digital (e-zine). Selain itu, penulis juga membuat media pendukung dalam perancangan ini yaitu media informasi. Tahap terakhir dalam metode ini adalah tahap Test. Pada tahap test ini dilakukan pengujian pada visualisasi dengan menyebarkan zine versi cetak dan versi digitalnya. Pengujian ini diperlukan untuk perbaikan dan pengembangan perancangan.

\section{PEMBAHASAN 3.1 Deskripsi Data}

Pada tahap emphatise, penulis melakukan pengamatan melalui penelusuran digital mengenai permasalahan yang dihadapi oleh para pemilih pemula terkait sikap politik, karakteristik, dan kebiasaan pemilih pemula dalam menggunakan media melalui data-data yang disajikan oleh media yang terpercaya. Pertama, penulis mendapatkan data dari laman daring Kompas yang memaparkan bahwa jumlah pemilih pemula tahun 2019 sebanyak 5.035.887 orang. Data tersebut berhadapan dengan data yang juga dikeluarkan oleh Litbang Kompas bulan Maret 2018 yang menyatakan bahwa 58,2\% responden di bawah 30 tahun hanya akan menggunakan hak pilih saja tanpa partisipasi aktif dalam perkembangan Pemilu 2019, 1,1\% menyatakan tidak akan mengikuti Pemilu, dan 1,1\% masih tidak tahu (Nugraheni, 2018). 
Data tersebut kemudian penulis konfirmasi dengan jajak pendapat melalui media sosial Instagram dan wawancara daring melalui aplikasi WhatsApp pada tanggal 2 Oktober 2018 kepada pemilih pemula. Hasilnya, dapat disimpulkan bahwa pemilih pemula dalam kelompok generasi z memilih apatis dalam Pilpres 2019, antara lain: pemahaman politik yang kurang, malas mengurus administrasi Pemilu 2019, bingung dan takut salah memilih pemimpin, pesimis terhadap masa depan bangsa, dan kurangnya literasi yang kekinian seputar politik. Penulis juga menemukan pendapat menarik dari sebuah ulasan mengenai generasi $\mathrm{z}$ yang merupakan pemilih pemula menurut Nastiti dalam Tirto.id (2017), generasi z atau pemilih pemula ini butuh formulasi pendidikan politik yang tepat sesuai dengan karakteristiknya. Generasi z telah jenuh dengan pidato yang hanya akan memicu sindiran dan narasi yang abstrak. Generasi ini jauh lebih tertarik dengan yang langsung bersentuhan dengan kehidupan sehari-hari.

Berdasarkan data tersebut, langkah kedua yang dilakukan penulis adalah mencari tahu kebiasaan pemilih pemula dalam menggunakan media. Penelusuran ini berguna untuk mengetahui bentuk komunikasi visual yang tepat sebagai edukasi politik bagi pemilih pemula. Penulis menemukan hasil survey yang menarik dari Tirto.id terhadap 1.201 responden generasi $\mathrm{z}$ di Jakarta, Bandung, Surabaya, Yogyakarta, Tangerang, dan Denpasar pada tanggal 9 Maret 2017 16 Juni 2017 yang disajikan dalam Visual Report berjudul Masa Depan di Tangan Generasi z memaparkan beberapa fakta. Generasi z rata-rata mengakses internet 3-5 jam/hari di mana 90\% nya mengakses dari ponsel pintar. Cara generasi z memperoleh berita adalah dengan mengakses melalui media sosial, browser, dan televisi. Akses paling besar adalah melalui media sosial yakni 35,2\% alasannya adalah kemudahan akses, intensitas pengguna media sosial yang banyak, dan informasi yang dirasa lengkap. Situs aplikasi yang sering diakses adalah Instagram (54,2\%), Line $(45,4 \%)$, dan Google $(42,1 \%)$. Ditinjau dari gaya hidupnya dalam survey yang sama menyebutkan bahwa $90 \%$ generasi z membeli produk di mall, pusat belanja, dan pasar. $70 \%$ dari mereka memutuskan sendiri merek yang mereka beli. Generasi z lebih banyak memilih makan di luar seperti restoran cepat saji atau coffee shop daripada makan di rumah.

Setelah melakukan penelusuran tersebut, penulis masuk ke dalam tahap define. Pada tahap ini penulis merumuskan masalah dan tujuan perancangan ini, yakni bagaimana merancang komunikasi visual yang dekat dengan pemilih pemula dalam kampanye sosial, sehingga dapat menumbuhkan kepedulian dalam Pilpres 2019. Penulis melakukan studi pustaka untuk mencari tahu lebih dalam mengenai karakteristik pemilih pemula. Pemilih pemula termasuk dalam kelompok generasi z, sebab menurut penelitian dari Bencsik, Csikos, dan Juhez (2016), generasi z merupakan generasi yang lahir dari 1995-2010. 
Setelah mendapatkan data tersebut, penulis mencari tahu mengenai karakter generasi $\mathrm{z}$ melalui teori dari Stillman (2017) mengungkapkan sifat menarik dari generasi z, yakni Figital. Sifat ini merupakan penggabungan dari kata fisik dan digital. Generasi z akan memadukan antara sisi fisik dan digital dalam konsumsi, kehidupan, dan pekerjaan. Ide tersebut juga didukung oleh sebuah analisis dari Bella (2018) mengenai iklan yang dikeluarkan oleh Leo Burnett, artikel tersebut mengemukakan bahwa sebuah kampanye sosial maupun iklan komersial dapat menarik di era Figital ini, apabila kampanye tersebut mampu memberikan penghargaan kepada orang-orang yang memberi perhatian pada konten mereka.

Komunikasi visual dalam perancangan ini dibuat untuk sebuah kampanye sosial yang bertujuan untuk menumbuhkan kepedulian pemilih pemula (generasi z) dalam Pilpres 2019. Tujuan tersebut ditegaskan dalam ide dari (Bloom dan Novelli, 1981 dalam Sharma, et.al 2012), yang mengemukakan bahwa niat di balik kampanye sosial adalah untuk memecah praktik perilaku yang tidak diinginkan dalam masyarakat atau untuk merangsang praktik yang diinginkan terhadap lingkungan, atau orang dan lingkungan sekitarnya. Dalam kaitannya dengan kampanye sosial kepada generasi z, Menurut Kleinschmit dalam Bussiness2Community (2017) mengemukakan bahwa, generasi z merespon edgy campaigns. Istilah edgy yang digunakan dalam bahasa Indonesia memiliki arti mengusik, mengganggu pemikiran dengan cara yang tidak biasa. Perlu ada cara baru baik dalam cara penyampaian pesan dan dalam pengolahan teknologi.

Berdasarkan data-data yang sudah penulis temukan, target audiens dalam perancangan ini dapat dipetakan. Proses ini dikerjakan dalam tahap selanjutnya, yakni ideate. Secara demografis target audiens dalam perancangan ini merupakan pemilih pemula dalam kelompok generasi z dengan usia 17-21 tahun dengan jenis kelamin laki-laki dan perempuan. Target audiens telah mendapat pendidikan formal yang baik, artinya sedang menempuh pendidikan di Sekolah Menengah Atas dan Perguruan Tinggi, namun belum mendapat pendidikan politik yang baik. Secara geografis, target audiens merupakan Warga Negara Indonesia yang tinggal di Indonesia. Secara psikografis, karakteristik dari generasi z antara lain, berpikiran terbuka, memiliki mobilitas yang tinggi, melawan rute tradisional, dan berani menjadi berbeda, namun dalam menghadapi permasalahan yang abstrak, cenderung dangkal. Ditinjau dari perilakunya, generasi lebih tertarik dengan hal-hal yang berhubungan dengan kehidupan sehari-hari dengan memilih media digital menjadi preferensi utama.

Penulis berangkat dari data-data di atas dalam melakukan pemilihan media. Berbagai media komunikasi visual dapat digunakan untuk menjadi kendaraan dalam menyampaikan pesan utama perancangan ini. Perancangan ini memiliki pesan besar tentang kepedulian terhadap Pilpres 
2019, yang bukan secara langsung menyampaikan larangan golput. Kepedulian yang dimaksudkan di sini adalah kesadaran dan kemauan diri pemilih pemula untuk mengkritisi calon presiden dan wakil presiden dalam kontestasi Pilpres 2019 melalui data-data yang terpercaya sebelum menentukan pilihan. Berdasarkan pesan utama dan mempertimbangkan karakter figital serta karakter-karakter target audiens lainnya yang sudah dipaparkan di atas, penulis memilih perpaduan media zine cetak dan zine digital (e-zine).

Zine merupakan media cetak sederhana yang dikerjakan secara independen baik perseorangan ataupun kolektif yang mengedepankan ekspresi, pendapat, dan pesan dari pembuatnya dapat tersampaikan (Bartel, 2004). Zine merupakan media alternatif untuk menyuarakan suatu pendapat politik daripada turun ke jalan. Zine adalah sebuah media yang berbeda bagi anak muda jika dibandingkan dengan media arus utama. Penulis berpendapat bahwa zine merupakan media yang tepat bagi perancangan ini karena karakteristik zine sesuai dengan karakteristik target audiens yang berani tampil berbeda dan melawan arus tradisional.

Zine yang menurut sejarahnya merupakan media dalam bentuk cetak, pada perancangan ini dikembangkan menjadi perpaduan dua bentuk media, yakni media cetak dan media digital ( $e$ zine). Perpaduan ini didasarkan pada teori Sinergi Antarmedia dari Kasilo (2008) yang menyatakan bahwa konsep sinergi antarmedia ini memungkinkan munculnya media yang tidak biasa atau tidak konvensional. Media-media yang digunakan tidak lagi didasarkan pada penempatannya atau materialnya, namun juga pada suasana dan budaya dari target audiens.

Pesan mengenai kepedulian adalah pesan yang abstrak. Penulis berpijak pada teori tentang metafora dari Lakoff dan Johnson (1980) yang memaparkan bahwa metafora bukan hanya terdapat pada bahasa atau karya sastra, namun lebih luas dari itu, metafora meresap dalam pemikiran dan tindakan. Metafora merupakan ide dan tindakan yang menerangkan sesuatu yang abstrak dengan mengidentifikasikannya dengan sesuatu yang lebih langsung, jelas dan lebih dikenal. Metafora merupakan strategi pesan yang dipilih oleh penulis sebab dapat membuat target audiens merasa dekat dengan pesan itu sendiri, sehingga lebih mudah memahami konsep pemikiran yang abstrak mengenai kepedulian. Sehingga melalui pemaparan di atas, pada bagian ini dapat disimpulkan bahwa perancangan ini merupakan perancangan komunikasi visual kampanye sosial peduli Pilpres 2019 bagi pemilih pemula, dengan menggunakan strategi media figital dan sinergi antarmedia serta strategi pesan verbal dan visual dengan gaya metafora.

\subsection{Pembahasan}

Pada bagian ini penulis akan menjelaskan mengenai tahapan berikutnya, yakni prototype dan test. Sebelum melakukan perwujudan karya desain dalam bentuk prototype, penulis 
memadukan data-data yang penulis temukan di tahap sebelumnya dengan ide dari penulis ke dalam sebuah konsep perancangan.

Pesan verbal dan visual yang ingin disampaikan, yakni di tengah pesimisme dan kondisi politik Indonesia yang tidak baik di mata pemilih pemula saat ini, masa depan bangsa ada di tangan pemilih pemula sebab mereka membawa harapan berupa hak pilih yang harus dibangkitkan dengan kepedulian dalam Pilpres 2019. Pesan tersebut didekati dengan metafora. Metafora yang digunakan untuk pemilih pemula adalah kata rookie, yang merupakan istilah dalam bahasa inggris artinya orang yang baru pertama kali mengikuti suatu kegiatan yang berkaitan dengan olah raga sehingga dekat dengan generasi z. Metafora yang dipilih untuk pesimisme dan kondisi politik Indonesia yang tidak baik adalah kata gelap. Kata gelap sering diidentifikasikan sebagai simbol hilangnya harapan, kematian, pesimisme, dan kekelaman. harapan berupa hak pilih yang harus dibangkitkan dengan kepedulian dalam Pilpres 2019 dimetaforakan dengan nyala lilin yang kecil. Nyala diidentikan dengan semangat dan harapan. Nyala dari api yang kecil merupakan sumber cahaya yang signifikan dalam kegelapan. Harapan berupa kepedulian dari masyarakat yang dianggap kecil dalam Pilpres 2019, dapat menumbuhkan optimisme dalam kondisi politik yang gelap. Metafora tersebut kemudian dijadikan judul kampanye sosial dan judul zine, yaitu: Rookie - Nyala dalam Gelap.

Langkah berikutnya, penulis menyusun pesan verbal. Pesan verbal dituturkan secara berurutan dari mulai memperkenalkan istilah Rookie, dilanjutkan dengan latar belakang hak pilih bisa dinikmati oleh masyarakat Indonesia melalui perjalanan memperjuangkan demokrasi dari tahun 1998 hingga 2004, dilanjutkan dengan esensi hak pilih, dampak pemanfaatan dan pengacuhan hak pilih bagi generasi z, dorongan untuk mencari sumber-sumber informasi yang kredibel yang bisa diakses sebagai wujud nyata kepedulian terhadap Pilpres 2019, satu cerita sederhana tentang membangkitkan harapan dan kepedulian, dan sebuah halaman yang mengarahkan pemilih pemula untuk membagikan apa yang sudah dibaca. Strategi tersebut dirancang dengan maksud supaya pembaca dapat memahami alur berpikir sebagai pemilih pemula yakni memahami esensi hak pilih terlebih dahulu lalu merasa harus memiliki preferensi politik yang jelas, sehingga dapat menunjukkan kepedulian dengan mencari informasi yang kredibel, akhirnya mampu memanfaatkan hak pilihnya dengan baik.

Setelah menentukan pesan verbal, penulis menentukan pesan visual. Digital Illustration digunakan sebagai teknik dalam perancangan ini karena merupakan lambang dari revolusi digital. Ilustrasi dalam zine ini menonjolkan beberapa unsur: figur-figur anak muda berusia 17-21 tahun yang akrab dengan gawai, mengenakan produk fashion dengan merek Adidas, Levi's, H\&M, 
Nike, Converse, Vans, dan Zara, nyala pada sebuah lilin untuk menunjukkan harapan, dan lilin yang mati untuk menunjukkan pesimisme.

Konsep warna yang digunakan dalam zine adalah monokrom nuansa hitam, abu-abu dengan satu aksen yakni, warna kuning. Nuansa abu-abu dan merepresentasikan kondisi kebimbangan pemilih pemula dalam menentukan preferensi politiknya dan hitam merepresentasikan gelapnya iklim politik di Indonesia saat ini. Warna kuning mewakili nyala yang dibawa oleh pemilih pemula, antusias, optimisme, tantangan, kebijaksanaan dan logika. Warna kuning juga mengarahkan psikologis manusia kepada pengambilan keputusan dengan kritis. Berikut adalah skema warna yang digunakan dalam perancangan ini:

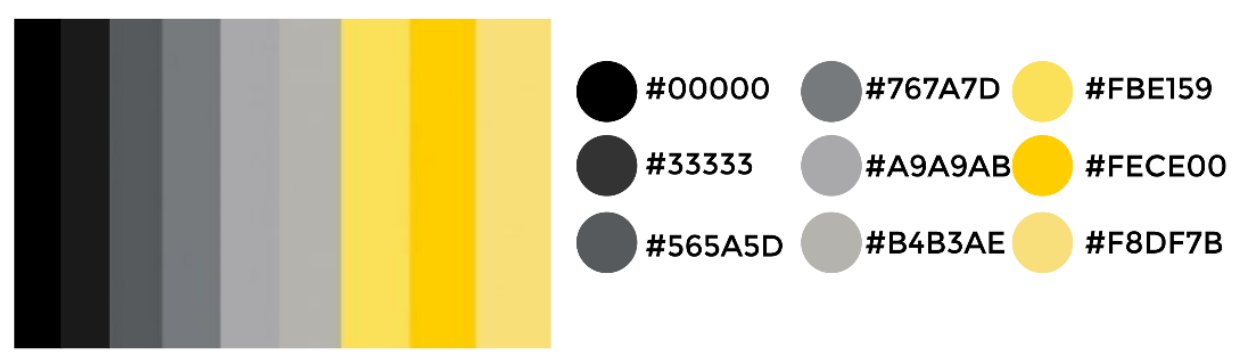

Gambar 2. Skema Warna (Sumber: Dokumentasi Penulis)

Konsep tipografi yang digunakan dalam perancangan ini adalah penggabungan antara kebebasan dan keteraturan yang dibalut dalam kesederhanaan. Kebebasan sebagai esensi dari zine dan karakteristik generasi $\mathrm{z}$ yang cenderung ingin menjadi berbeda diwakili oleh jenis HandLettering (Free Hand) dan keteraturan diwakili oleh jenis huruf Sans-Serif yang teratur dan keterbacaannya mudah. Hand-Lettering (Free Hand) digunakan untuk teks yang menyampaikan sebuah quotes dan headline. Sedangkan Sans-Serif digunakan untuk bodycopy.

Konsep tata letak yang dipilih adalah Young \& Fun Layout. Desain Young and Fun dibuat sedikit lebih dewasa, dengan tampilan yang tidak lagi kekanak-kanakan, namun tetap terasa muda. Konsep dipilih ini untuk mengemas pesan dengan lebih kekinian, muda, dan menyenangkan.

Setelah melakukan konsep perancangan pesan visual, penulis merancang program media. Pada perancangan ini, zine dipublikasikan dengan dua cara dalam waktu yang bersamaan baik diunggah di layanan berbagi di internet yaitu Google Drive berupa e-zine (zine digital), dipublikasikan secara langsung di kedai kopi yang merupakan tempat berkumpulnya pemilih pemula. Ada 2 jenis zine yang dicetak, yakni zine berwarna dan zine hitam-putih. Zine berwarna hanya boleh dibaca di tempat, dan zine hitam putih boleh dibawa pulang dan digandakan dengan 
mesin fotokopi, di dalam zine cetak terdapat $Q R$ Code (Quick Response Code). Kode tersebut dapat dipindai melalui gawai pemilih pemula dan langsung terhubung ke tautan unduh $e$-zine. Setelah diunduh, pemilih pemula akan memiliki $e$-zine yang sama dengan format cetak dan dapat membagikan ulang kepada pemilih pemula lainnya melalui media sosial atau aplikasi percakapan. Pemilih pemula diarahkan untuk memberikan tagar \#NyalaDalamGelap untuk foto halaman zine yang dibagikan melalui media sosial. Langkah ini digunakan untuk mempermudah penulis dalam tahap test, untuk menguji sejauh mana kampanye sosial sudah berjalan. Setiap pembaca zine berhak mendapat 1 pak stiker terbatas yang diminta ke pelayan kedai kopi sebagai apresiasi atas keterlibatan dalam kampanye sosial.

Setelah membuat program media, penulis membuat sketsa zine. Beikut adalah sketsa dari zine dalam perancangan ini:

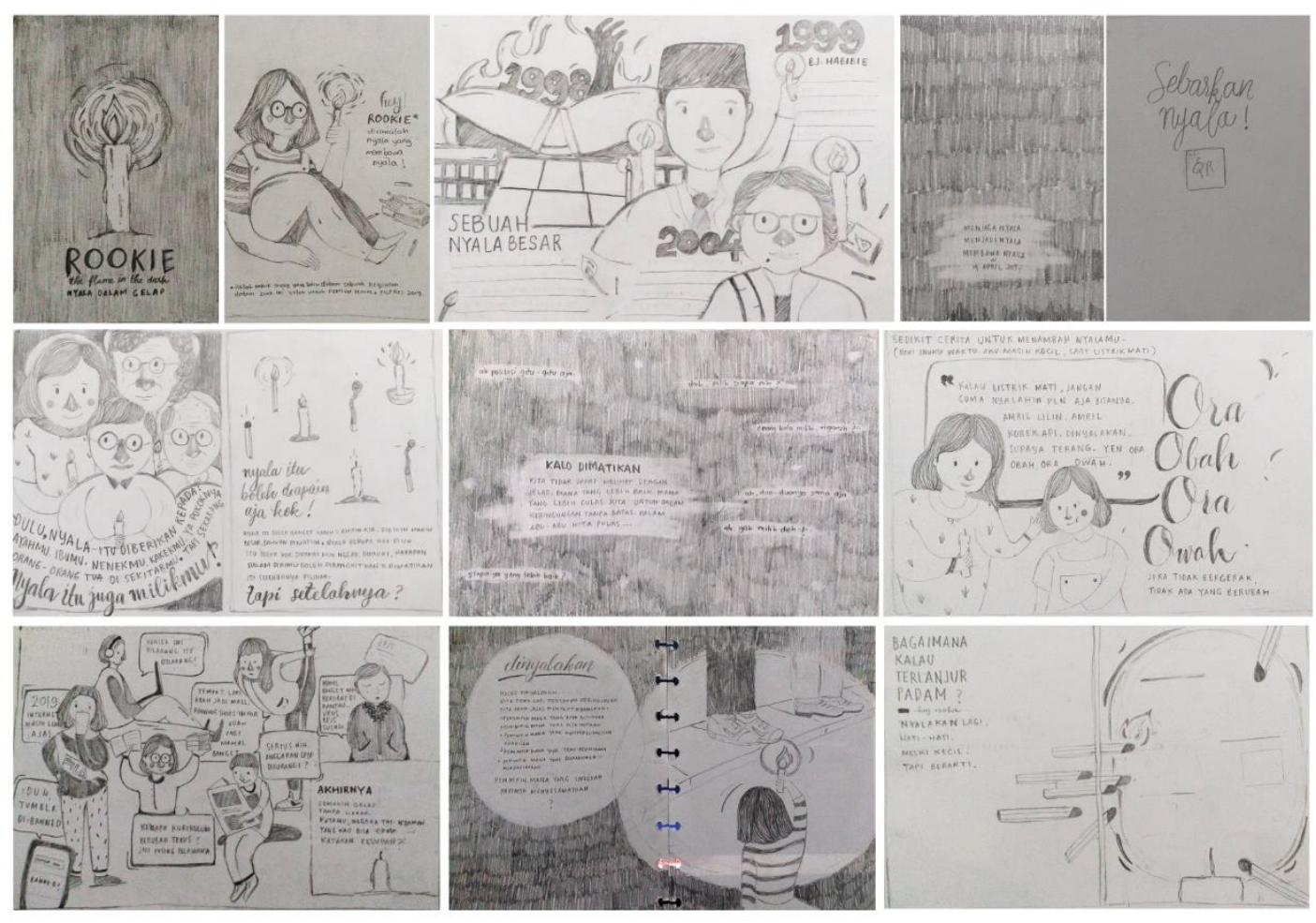

Gambar 3. Sketsa Zine

(Sumber: Dokumentasi Penulis)

Sketsa di atas kemudian penulis proses ke dalam proses digitalisasi disebut juga dengan desain komperhensif. Kemudian desain tersebut diaplikasikan ke dalam cetak biru atau prototype sebelum dicetak dan diunggah. Hasil akhir dari karya desain kemudian diunggah dan diberikan nama tautan. Pada perancangan ini e-zine diunggah ke dalam Google Drive dalam tautan: bit.ly/NyalaDalamGelap. Berikut adalah hasil karya desain zine berdasarkan halaman: 


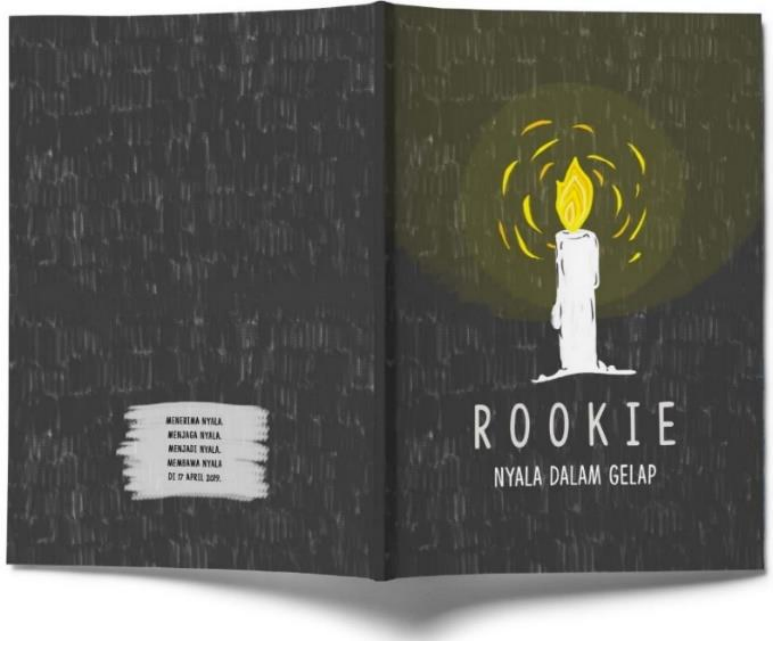

Gambar 4. Karya Desain Zine: Sampul Depan dan Sampul Belakang (Sumber: Dokumentasi Penulis)

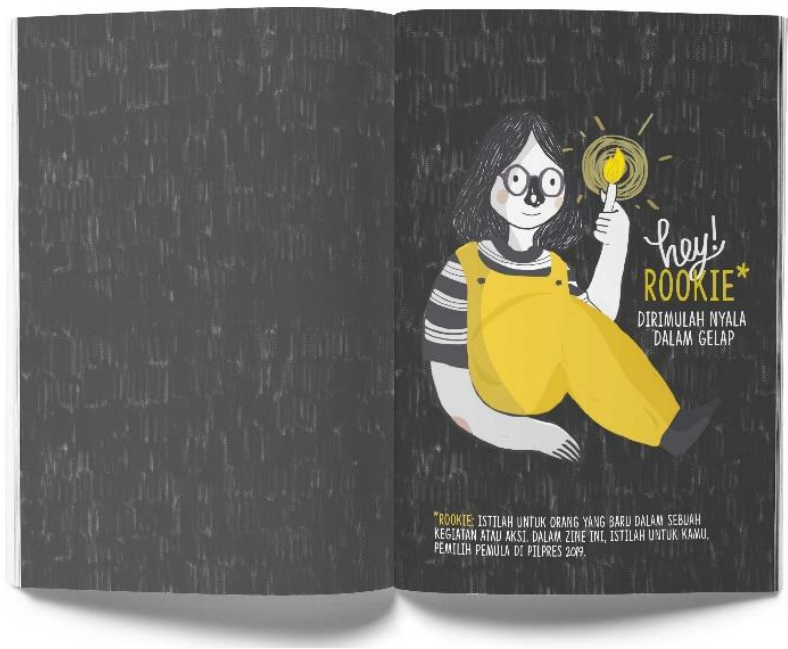

Gambar 5. Karya Desain Zine: Sampul Dalam dan Halaman 1 (Sumber: Dokumentasi Penulis)

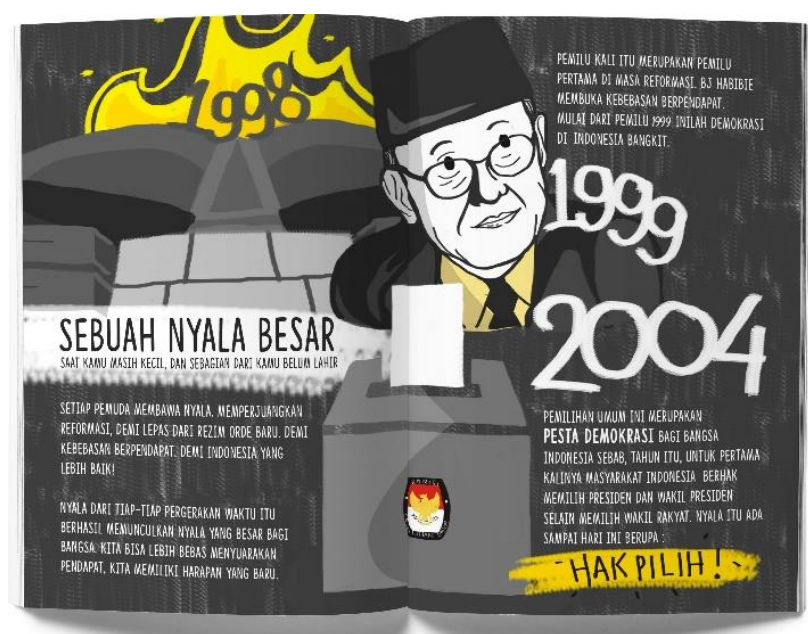

Gambar 6. Karya Desain Zine: Halaman 2 dan 3 (Sumber: Dokumentasi Penulis) 


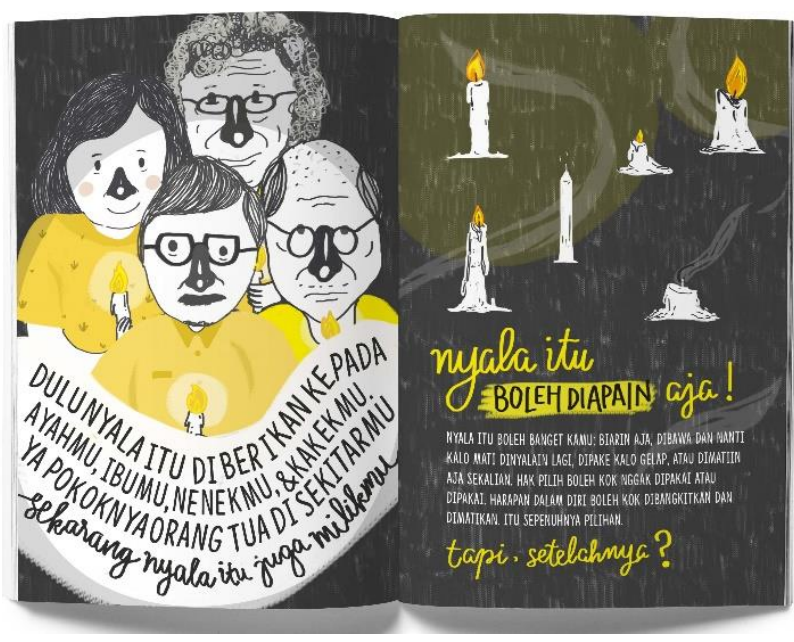

Gambar 7. Karya Desain Zine: Halaman 4 dan 5 (Sumber: Dokumentasi Penulis)

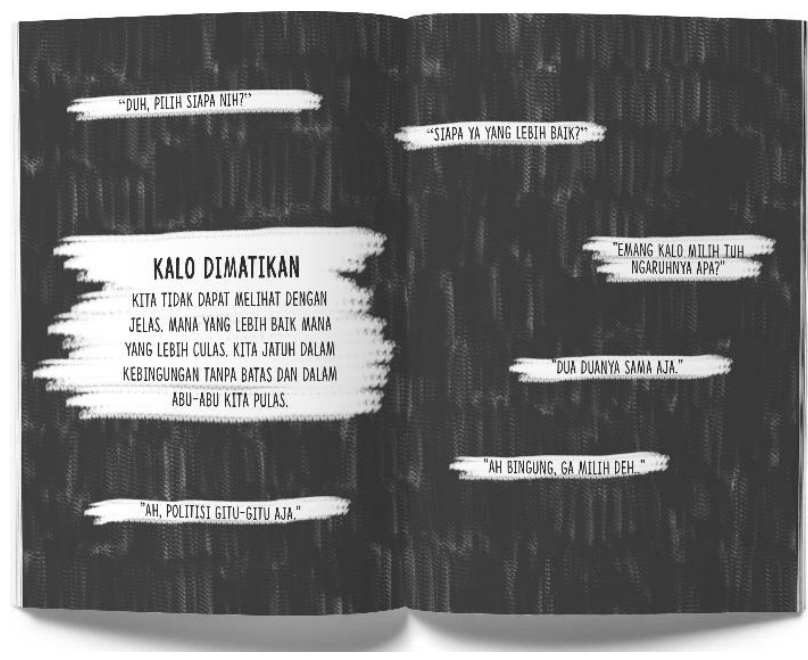

Gambar 8. Karya Desain Zine: Halaman 6 dan 7 (Sumber: Dokumentasi Penulis)

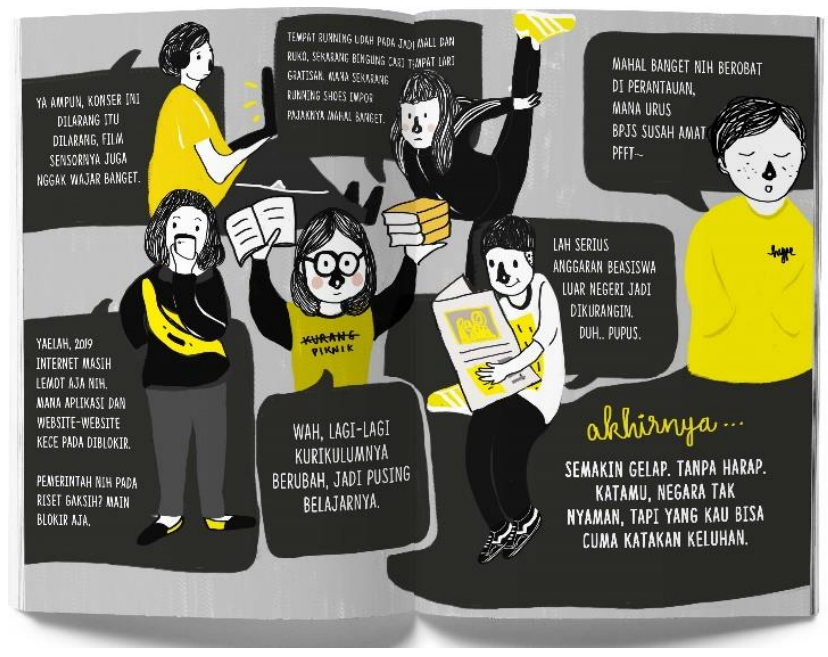

Gambar 9. Karya Desain Zine: Halaman 8 dan 9 (Sumber: Dokumentasi Penulis) 


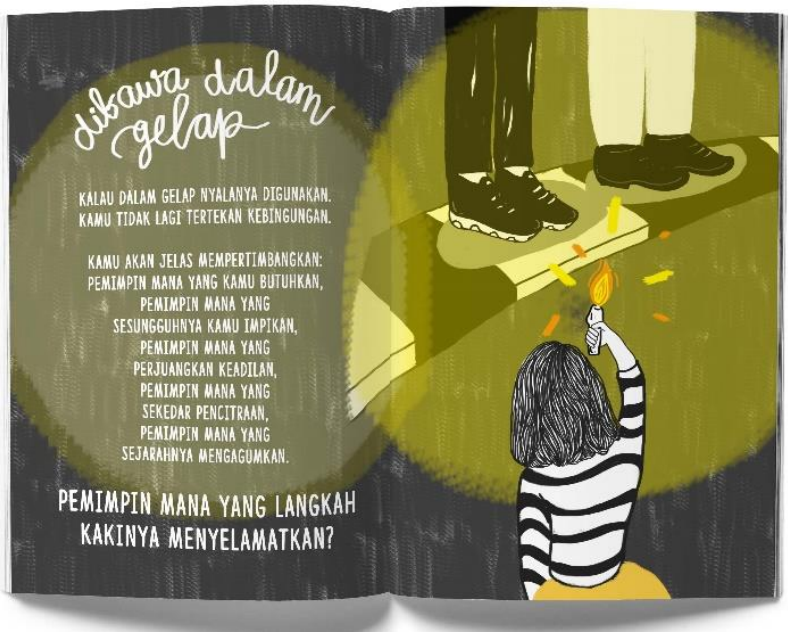

Gambar 10. Karya Desain Zine: Halaman 10 dan 11 (Sumber: Dokumentasi Penulis)

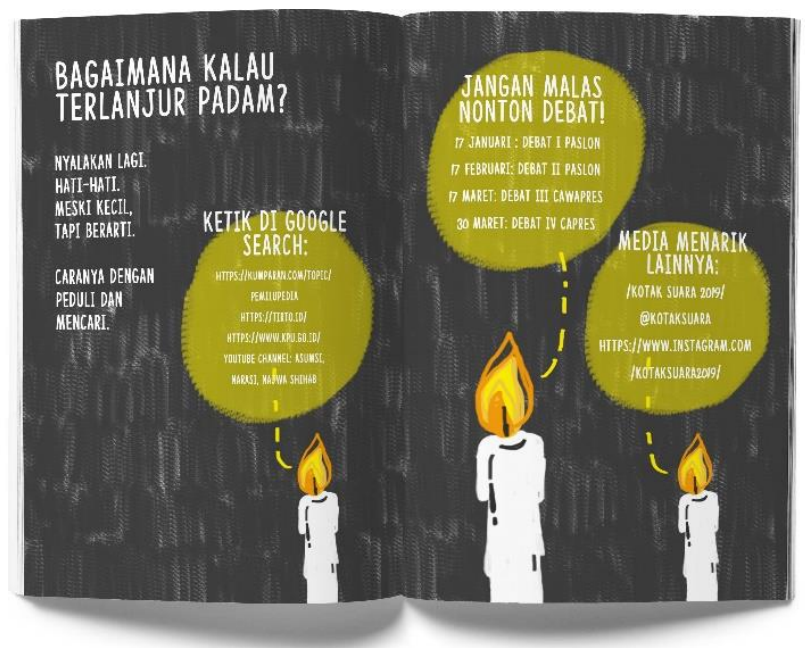

Gambar 11. Karya Desain Zine: Halaman 12 dan 13 (Sumber: Dokumentasi Penulis)

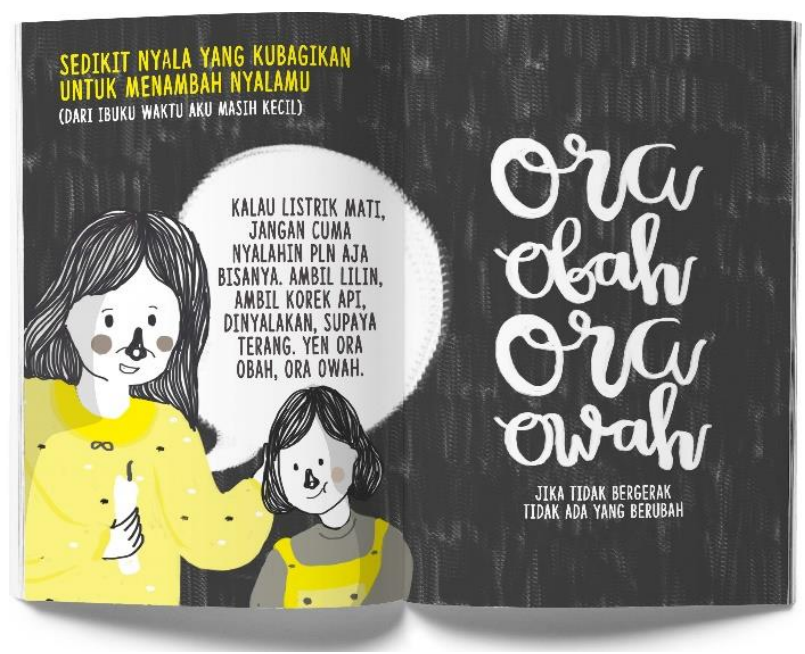

Gambar 12. Karya Desain Zine: Halaman 14 dan 15 (Sumber: Dokumentasi Penulis) 


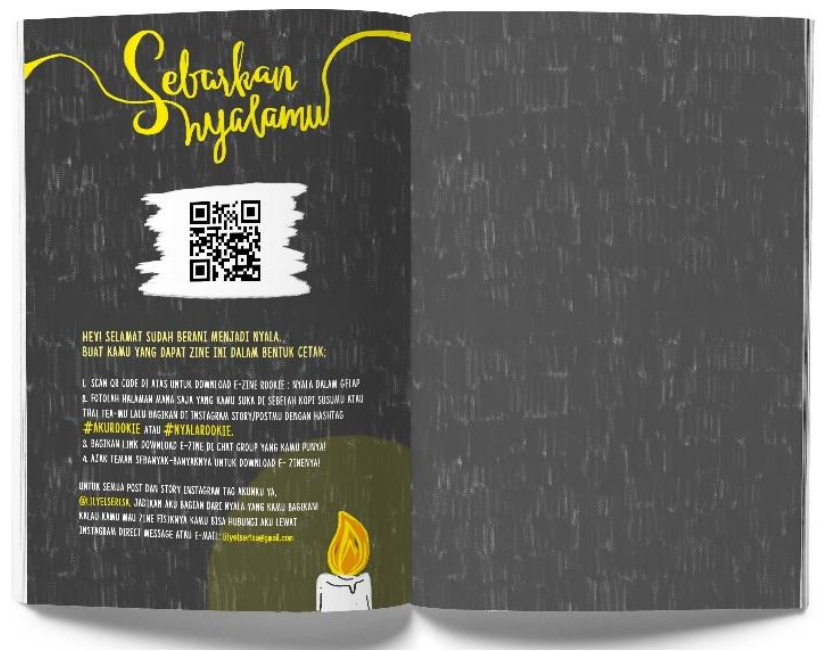

Gambar 13. Karya Desain Zine: Halaman 16 dan Sampul Dalam (Sumber: Dokumentasi Penulis)

Selain zine cetak dan e-zine sebagai media utama, penulis juga merancang media pendukung sesuai kebutuhan dari target audiens berupa poster untuk publikasi dan stiker sebagai apresiasi keterlibatan. Saat ditempel di berbagai fasilitas pribadi, target audiens akan terus mengingat tentang pesan dari kampanye sosial. Media pendukung ini tidak serta merta sebagai pelengkap namun juga bersinergi dengan media zine itu sendiri. Poster cetak yang digunakan saat peluncuran kampanye sosial pada tahap test dilengkapi dengan $Q R$ Code untuk mengunduh $e$-zine. Berikut hasil karya desain dari media-media tersebut:

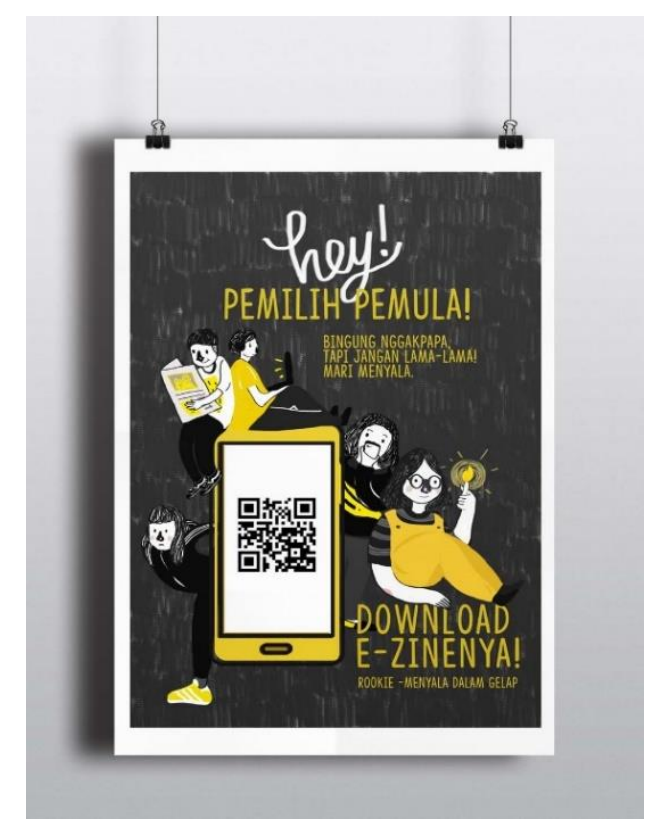

Gambar 14. Poster publikasi sebagai media promosi (Sumber: Dokumentasi Penulis) 


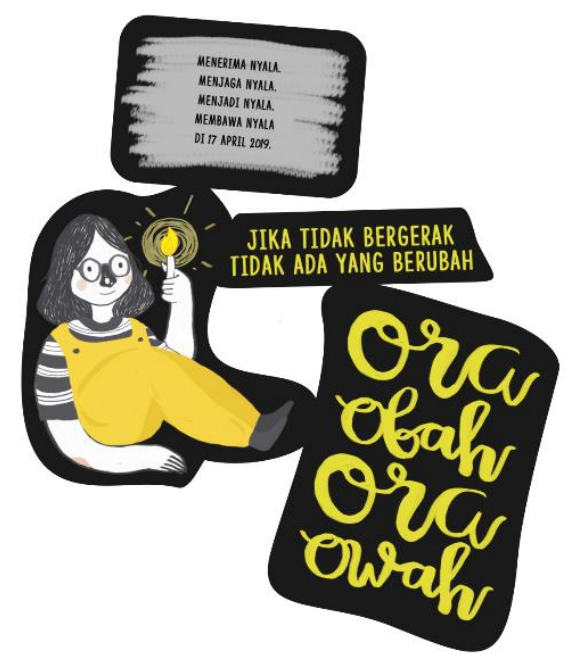

Gambar 15. Sticker Pack untuk apresiasi keterlibatan (Sumber: Dokumentasi Penulis)

\section{KESIMPULAN}

Komunikasi visual yang dirancang dalam sebuah kampanye sosial dengan tujuan menumbuhkan kepedulian pemilih pemula dalam Pilpres 2019 perlu menggunakan strategi pesan yang dekat dengan target audiens. Selain itu, diperlukan suatu strategi pemilihan media alternatif yang dapat mengisi ruang digital dan ruang fisik generasi z. Melalui metode perancangan Design Thinking, tahap empathise dan define berguna untuk memahami target audiens dengan mendalam sehingga karakteristik dan kebutuhan target audiens terhadap wujud dan bentuk media komunikasi visual dapat diketahui. Karakteristik dan kebutuhan target audiens yang telah dipahami dapat memperkaya dan memperdalam ide dan konsep perancangan.

Dalam perancangan ini, pesan verbal dan visual dalam kampanye sosial disampaikan dengan menggunakan metafora atau perumpamaan yang dekat dengan kehidupan sehari-hari pemilih pemula (generasi z) dengan mempertimbangkan budaya digital generasi z dalam visualisasinya. Pesan tersebut disampaikan melalui media komunikasi visual dengan strategi sinergi antarmedia, sehingga pemilih pemula dapat menerima pesan tersebut baik secara digital maupun fisik atau cetak. Penulis berharap perancangan ini bukan hanya dapat menumbuhkan kepedulian pemilih pemula dalam Pilpres 2019, namun juga memberikan inspirasi bagi perancangan komunikasi visual dalam kampanye sosial yang bertujuan mendorong generasi muda untuk terlibat aktif dalam praktik demokrasi di Indonesia. 


\section{DAFTAR PUSTAKA}

Bartel, Julie., 2004. From A to Zine. Chicago: American Library Association.

Bencsik, A., Csikos, G., \& Juhaz, T. 2016. Y and Z Generations at Workplaces. Journal of Competitiveness, Vol. 8, No.3. Hal: 90-106.

Brown, Tim. (2009). Change by Design: How Design Thinking Transforms Organizations and Inspires Innovation. United States: HarperCollins.

Business2Community, Generation Z characteristics: 5 infographics on the Gen Z Lifestyle. (Updated 4 Desember 2015) URL:

https://www.business2community.com/infographics/generation-z-characteristics-5infographics-gen-z-lifestyle-01394477. Diakses 21 Desember 2018.

Kasilo, Djito., 2008. Komunikasi Cinta: Menembus G-Spot Konsumen Indonesia. Jakarta: Kepustakaan Populer Gramedia

Kompas.com, 2018. Saran Kemendagri agar Pemilih Pemula Bisa Mencoblos pada Pemilu 2019. (Updated 17 September 2018) URL:

https://nasional.kompas.com/read/2018/09/17/15350161/saran-kemendagri-agar-pemilihpemula-bisa-mencoblos-pada-pemilu-2019. Diakses 30 Oktober 2018

Lakoff, George dan Johnson, Mark., 2003. Methaphors We Live By. Chicago: The University of Chicago Press.

Nugraheni, Anita., 2018. Jajak Pendapat: Pemilih Muda Rentan Berubah. Jakarta: Kompas

Sharma A, Bhosle A, Chaudary B. 2012. Consumer Perception and Attitude towards the Visual Elements in Social Campaign Advertisement. IOSR Journal of Business and Management (IOSRJBM), 06-17

Stillman, David \& Jonah., 2017. Gen Z @ Work: How The Next Generation is Transforming The Workplace. New York: Harper Collins Publisher

Tirto.id, 2017. Memahami Aspirasi dan Perilaku Politik Generasi Z. (Updated 16 Agustus 2017) URL: https://tirto.id/memahami-aspirasi-dan-perilaku-politik-generasi-z-cuEL. Diakses 20 Desember 2018

Tirto.id, 2017. Visual Report: Masa Depan di Tangan Generasi Z. (Updated: Agustus 2018) URL: https://tirto.id/tirto-visual-report-masa-depan-di-tangan-generasi-z-ctMM. Diakses tanggal 20 Desember 2018 